predicted epidemic, a change in immunisation strategy will be required to eliminate measles. Uniform coverage of $95 \%$ with a $100 \%$ effective vaccine will be required to eliminate measles in a stable population. ${ }^{5}$ My results indicate that at current immunisation coverage, $6 \cdot 8 \%$ of children would remain completely unimmunised with a two dose measles schedule incorporating a preschool booster. Given a primary vaccine failure of $5-10 \%$ for both immunisations and no acquired natural immunity before going to school, between $7 \cdot 7 \%$ and $8.8 \%$ of children would remain susceptible to measles. At these rates a further primary school measles immunisation campaign might be necessary within the next few years.

National coverage of measles, mumps, and rubella immunisation has risen considerably over the past five years and preschool booster coverage is also improving (in South Glamorgan, from $84.2 \%$ in the 1985 birth cohort to $87.8 \%$ in the 1989 birth cohort). This means that a higher proportion of children could be protected against measles by a two dose strategy in future birth cohorts. To ensure success, however, greater efforts will have to be concentrated on tracing persistent non-attenders for immunisation and on improving preschool booster coverage.

I thank the Welsh Health Common Services Authority's child support team for providing the immunisation data for South Glamorgan.

1 White JM, Leon S, Ramsay MEB. COVER (Cover of vaccination evaluated rapidly):31. Commun Dis Rep CDR Rev 1994:4:129-30.

2 Ramsay N, Gay N, Miller E, Rush M, White J, Morgan-Capner P, et al. The epidemiology of measles in England and Wales: rationale for the 1994 national vaccination campaign. Commun Dis Rep CDR Rev 1994;4:141-6.

vaccination campaign. Commun Dis Rep CDR Rev 1994;4:141-6
Miller E. The new measles campaign. BMf 1994;309:1102-3.

4 Erdman DD, Heath JL, Watson JC, Markowitz LE, Bellini WJ. Immunoglobulin $M$ antibody response to measles virus following primary and secondary vaccination and natural virus infection. $\mathcal{F}$ Med Virol 1994;41:44-8.

5 Tulchinsky TH, Ginsberg GM, Abed Y, Angeles MT, Akukwe C, Bonn J. Measles control in developing and developed countries: the case for a two dose policy. Bull World Health Organ 1993;71:93-103.

(Accepted 9 March 1995)
Institute of Food Research, Norwich Laboratory, Norwich NR4 7UA

S J Fairweather-Tait, head of mineral metabolism group

T E Fox, research scientist A Mallillin, research scientist

Correspondence to: S J Fairweather-Tait.

$B M 7$ 1995;310:1368

\section{Balti curries and iron}

\section{S J Fairweather-Tait, T E Fox, A Mallillin}

Iron deficiency anaemia is the most prevalent nutritional problem in the world today and is recognised as a particular problem in developing countries. Those considered to be at greatest risk of developing nutritional iron deficiency are young children and women of reproductive age, especially pregnant and lactating women. Most cases of iron deficiency anaemia can be prevented or treated by iron supplementation and good nutrition.

The use of cast iron cookware has been shown to increase the iron content of food, ${ }^{1}$ and the bioavailability of this contaminant iron has been shown to be high. ${ }^{2}$ Although the use of cast iron cookware is not particularly widespread in the United Kingdom, it seems to be gaining in popularity and is specifically used in the preparation of an Indian cuisine known as balti, where the food (a curry) is served straight from a small cast iron wok. Recently cook-chill balti meals have been introduced into high street supermarkets, so we undertook a study to compare the iron content of these meals prepared in a cast iron balti wok with the food as bought.

\section{Methods and results}

Three cook-chill meals-a vegetable curry, a chicken curry, and a balti vegetable curry-were obtained from Sainsbury's supermarket. All three meals were divided into two weighed portions with one portion being

Iron content ${ }^{*}$ of commercially prepared curry meals before and after cooking in a cast iron balti wok

\begin{tabular}{lcc}
\hline Food & $\begin{array}{c}\text { Iron as purchased } \\
(\mathrm{mg} / 100 \mathrm{~g})\end{array}$ & $\begin{array}{c}\text { Iron after cooking } \\
(\mathrm{mg} / 100 \mathrm{~g})\end{array}$ \\
\hline Vegetable curry & 0.86 & 10.67 \\
Chicken balti & 1.54 & 12.73 \\
Vegetable balti & 1.46 & 6.15 \\
\hline
\end{tabular}

`The maximum assay variability was $0.8 \mathrm{mg} / 100 \mathrm{~g}$. cooked in a balti wok on a low gas ring for 20 minutes. Both portions of each meal were freeze dried and ashed in a muffle furnace at $480^{\circ} \mathrm{C}$ for 48 hours and the iron content of each portion analysed in triplicate by flame atomic absorption spectrophotometry. ${ }^{3}$

The results of the analysis of iron content showed a considerable increase in all of the meals cooked in the balti wok (see table).

\section{Comment}

These data suggest that the iron intake of people consuming traditional balti meals could be extremely high, falling well outside the normal range of dietary intake (10-12 mg/day). ${ }^{4}$ For example, a meal of chicken and vegetable balti dishes could provide about $50 \mathrm{mg}$ of iron. This would be a very useful source of dietary iron for vulnerable members of the population, such as women, $14 \%$ of whom have little or no body iron stores (serum ferritin $<13 \mu \mathrm{g} / \mathrm{l}$ ) and $4 \%$ of whom have iron deficiency anaemia. ${ }^{4}$

Giving dietary advice on iron is not easy because the absorption of iron from meals varies greatly. In fortified foods the chemical form of the added iron affects its bioavailability, which may in some instances be low. One of the richest sources of well absorbed iron is liver ( $7 \mathrm{mg}$ iron/portion), but this contains considerably less iron than meals cooked in the balti wok. Foods prepared in cast iron cookware, such as balti curries, could therefore be included in the list of foods high in iron recommended for people with an existing or potential problem of iron deficiency. Except for people with hereditary haemochromatosis, who should be advised to avoid balti curries prepared in cast iron cookware, our findings show that balti meals not only add spice to your life but also provide a useful quantity of potentially absorbable iron.

1 Brittin HC, Nossaman CE. Iron content of food cooked in iron utensils. $f \mathrm{Am}$ Dietic Assoc 1986;86:897-901.

Martinez FE, Vannuchi H. Bioavailability of iron added to the diet by cooking in an iron pot. Nutr Res 1986;6:421-8.

3 Fairweather-Tait SJ, Wright AJA. The effects of sugar-beet fibre and wheat bran on iron and zinc absorption in rats. Br 7 Nutr 1990;64:547-52.

Gregory J, Foster $\mathrm{K}$, Tyler $\mathrm{H}$, Wiseman $\mathrm{M}$. The dietary and nutritional survey of British adults. London: HMSO, 1990.

(Accepted 31 March 1995) 